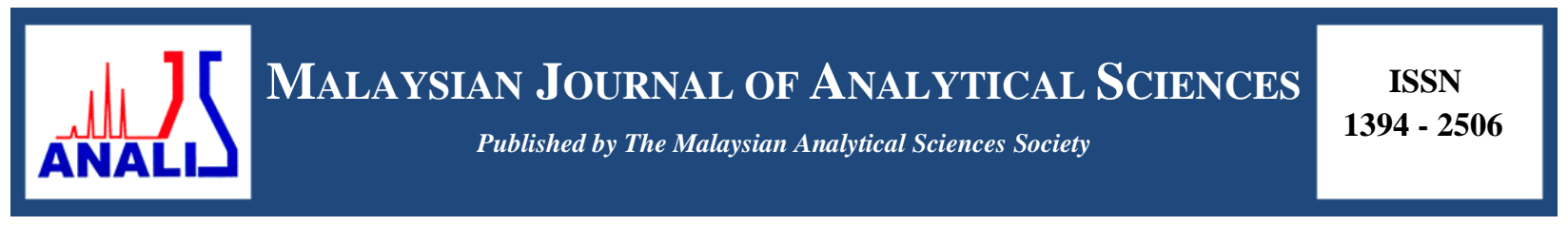

\title{
MESOPOROUS SILICA ELECTROCHEMICAL SENSORS FOR THE DETECTION OF ASCORBIC ACID AND URIC ACID
}

\section{(Sensor Elektrokimia Silika Berliang Meso untuk Pengesanan Asid Askorbik dan Asid Urik)}

\author{
Hashazirah Mohamad Hassan*, Nurul Barakah Ab Rahman, Mohammad Noor Jalil \\ School of Chemistry and Environment, \\ Faculty of Applied Science, \\ Universiti Teknologi MARA, 40450 Shah Alam, Selangor, Malaysia \\ *Corresponding author: hashazirah@gmail.com
}

Received: 24 February 2015; Accepted: 27 October 2015

\begin{abstract}
Mesoporous silica of SBA-15 and SBA-16 were successfully synthesized via the surfactant templating technique using tetraorthosilicate (TEOS) as the silica source and both surfactants, pluronic P123 and F127. Two different modified carbon paste electrodes (MCPE) were fabricated; SBA-15/MCPE and SBA-16/MCPE in compared to unmodified electrode, carbon paste electrode (CPE), for ascorbic acid (AA) and uric acid (UA) determination. Due to the unique properties of mesoporous silica materials, the MCPE fabricated exhibits greater surface enhancement effect, offers better adsorption and increases the response signals of AA and UA towards both MCPEs compared to CPE. The electrochemical behaviours of AA and UA were investigated using cyclic voltammetry. Finally, the electrochemical methods were successfully applied in detection of AA and UA.
\end{abstract}

Keywords: mesoporous silica, electrochemical sensor, SBA-15, SBA-16, synthesis, electrochemical methods

\begin{abstract}
Abstrak
Mesoporus silika SBA-15 dan SBA-16 telah disintesis dengan jayanya melalui teknik templat surfaktan menggunakan tetraortosilikat (TEOS) sebagai sumber silika dan kedua-dua surfaktan, Pluronic P123 dan F127. Dua elektrod pes karbon yang dimodifikasi (MCPE) yang berbeza, SBA-15/MCPE dan SBA-16/MCPE telah dihasilkan dan dibandingkan dengan elektrod pes karbon yang tidak dimodifikasikan (CPE), untuk penentuan asid askorbik (AA) dan asid urik (UA). Dengan sifat-sifat unik bahan silika, MCPE yang telah difabrikasi mempamerkan peningkatan efek permukaan yang baik, penjerapan yang lebih bagus, dan peningkatan signal respon AA dan UA terhadap kedua-dua MCPE berbanding CPE. Perlakuan elektrokimia AA dan UA telah dikenalpasti dengan menggunakan alat voltametri berkitar. Akhirnya, kaedah elektrokimia telah berjaya diaplikasikan dalam pengesanan AA dan UA.
\end{abstract}

Kata kunci: silika berliang meso, sensor elektrokimia, SBA-15, SBA-16, sintesis, kaedah elektrokimia

\section{Introduction}

Electrochemical sensor is a smart network that acts as an important component in the multifunctional intergrated electrical devices [1]. Electrochemical sensor has been widely discovered in its field of studies. It is commonly used in the detection of favoured molecules [2], hormones [3] or organic compound [4]. AA is an anti-oxidant that influences physiological processes in human body [5]. UA is the primary end product of purine metabolism [6]. AA and UA are considered as important molecules in human metabolism but the improper concentration level of the compounds may lead to various serious diseases. Therefore, the determination of AA and UA in analytical determination and diagnostic research is vital [7]. And to date, various electrochemical methods were developed in 
detection of AA and UA utilizing different types of electrodes for example one-dimensional MgO biosensor [8], $\mathrm{TiO}_{2}$ nanoparticles MCPE [9], Pt nanoparticles supported graphene oxide [10] and reduced grapheme oxide modified electrode [11]. Although there are several research works reported on the determination of AA and UA using mesoporous silica mainly type MCM-41 [12, 13], however, to the best of our knowledge, electrochemical detection of AA and UA using, SBA-15 and SBA-16, has not been reported.

Since the mesoporous silica has been discovered since two decades ago [14], the interest in this field have grown wider and attracted scientist worldwide. Mesoporous silica has large surface area, high pore volume, wide range of pore sizes, and unique mesoporous channels resulting an excellent surface enhancement effect [15, 16], but, its existence in electrochemistry is still very rare [13]. The unique properties of mesoporous silica makes it an excellent component in fabricating electrochemical sensor. With the presence of mesoporous silica, a MCPE provides surface and adsorption enhancement towards the determination of favoured molecules [17-19]. The main objectives of this study was to successfully synthesize the mesoporous silica; SBA-15 and SBA-16 and to build a convenient, cheap, enhanced and sensitive electrochemical method (SBA-15/MCPE and SBA-16/MCPE) for the determination of AA and UA by utilizing the properties of SBA- 15 and SBA- 16 .

\section{Chemicals and raw materials}

\section{Materials and Methods}

All the chemicals used were of analytical grade and purchased from; Tetraethoxysilane, TEOS (98\%, Aldrich), triblock copolymer Pluronic F127, $\mathrm{EO}_{106} \mathrm{PO}_{70} \mathrm{EO}_{106}$ (Sigma-Aldrich), tri-block copolymer Pluronic P123, $\mathrm{EO}_{20} \mathrm{PO}_{70} \mathrm{EO}_{20}$ (Sigma-Aldrich), Paraffin oil (Biobasic), Graphite powder ( $<20 \mu \mathrm{m}$, Aldrich) Hydrochloric acid, $\mathrm{HCl}$ (36\%, Aldrich), Methanol, $\mathrm{CH}_{4} \mathrm{O}$, Ethanol, $\mathrm{C}_{2} \mathrm{H}_{6} \mathrm{O}$, deionized water, platinum wire, Pt, silver wire, Ag (SigmaAldrich), copper wire, $\mathrm{Cu}$, Uric acid, L-Ascorbic acid (vitamin C) (ACS grade, Biobasic), glass tube, epoxy glue.

\section{Instruments}

The characterization of the mesoporous materials were investigated using both Rigaku D/max-2500 powder diffractometer with $\mathrm{Cu}-\mathrm{K} \alpha$ source ( $2 \theta$ mode, continuous scanning; $40 \mathrm{kV}, 20 \mathrm{~mA}$ ) and SUPRA 40 FE-SEM from Carl Zeiss AG. Electrochemical measurements were carried out using an Autolab PGSTAT101 potentiostat from Metrohm Autolab B.V. A three-electrode system, consisting of a working electrode (carbon paste electrode (CPE) as well as mesoporous silica modified carbon paste electrode (MCPE), a reference electrode $(\mathrm{Ag} / \mathrm{AgCl})$ and a counter electrode (platinum wire).

\section{Synthesis of SBA-15 and SBA-16}

The preparation of SBA-15 was adapted from Sayari et al. [20] and minorly modified as follows; $4.0 \mathrm{~g}$ of Pluronic $\mathrm{P} 123$ was dissolved in $30 \mathrm{ml}$ of deionized water and $120 \mathrm{ml}$ of $2 \mathrm{M} \mathrm{HCl}$ in a closed container while stirring at $35{ }^{\circ} \mathrm{C}$ for 20 hours. $8.50 \mathrm{~g}$ of TEOS was added slowly to the mixture with vigorous stirring for 15 minutes. The mixture was then kept under static condition at constant temperature $\left(35^{\circ} \mathrm{C}\right)$ for 20 hours and transferred to an oven for 24 hours at $90{ }^{\circ} \mathrm{C}$ (hydrothermal process). The white precipitation obtained were separated by vacuum filtration. The resulting white solids was then washed with deionized water and dried for 3 days at $45^{\circ}$. Finally, sample was calcined at $500{ }^{\circ} \mathrm{C}$ in air for 6 hours to remove surfactants from mesopores.

The SBA-16 was synthesized according to procedures adapted and minorly modified from Sun \& Jun and Boissiere et al. [21, 22]. A amount $2.3 \mathrm{~g}$ of Pluronic F127 was dissolved in $0.6 \mathrm{ml}$ concentrated $\mathrm{HCl}$ and $103.4 \mathrm{ml}$ methanol with continuous stirring for 2 hours at $35{ }^{\circ} \mathrm{C}$. In a separate beaker, $10.4 \mathrm{ml}$ TEOS, $5.2 \mathrm{ml}$ ethanol and $4.2 \mathrm{ml}$ deionized water were mixed and stirred for 30 minutes at room temperature. The second mixture was slowly added to the first and stirred for an hour at $35{ }^{\circ} \mathrm{C}$. The solution was then kept under static condition for 20 minutes (hydrothermal treatment) at $80^{\circ} \mathrm{C}$. Then, the solution was cooled down at ambient temperature for 4 hours before it was transferred in a closed container and heated for 24 hours at $90{ }^{\circ} \mathrm{C}$ to enhance the formation of silica crosslink. Finally, sample was calcined at $500{ }^{\circ} \mathrm{C}$ for 10 minutes.

\section{Fabrication of electrochemical sensor}

Three types of electrodes were prepared including unmodified carbon paste electrode. The following methods are adapted and slightly modified from Fathirad et al. [23]. The bare carbon paste electrode (CPE) was prepared by 
mixing graphite powder with few drops of paraffin oil. While the modified carbon paste electrodes (MCPE) are prepared by mixing $0.85 \mathrm{~g}$ of mesoporous silica SBA-15 and $0.15 \mathrm{~g}$ graphite powder with the addition of paraffin oil droplets. And the same procedure for SBA-16/MCPE. The pastes were then packed and tightly pressed into the cavity of the glass tubes resulting 3 different electrodes. Electrical contacts are provided by implementing copper wire inside the tube. Finally, the bottom surface of sensors were polished using smooth paper and washed with deionized water.

\section{Analytical procedure}

Unless otherwise stated, $\mathrm{pH} 7.0$ phosphate buffer $(0.05 \mathrm{M})$ was used as the supporting electrolyte for both AA and UA. The cyclic voltammetry curves were recorded from 0.0 to $1.0 \mathrm{~V}$ per cycle, and oxidation peak currents were individually measured at $0.24 \mathrm{~V}$ and $0.79 \mathrm{~V}$.

\section{Structural characterization of mesoporous silica}

\section{Results and Discussion}

The SEM micrographs shows SBA-15 possessing rod-like shape (Figure 1a) when P123 was used as directing agent with TEOS as the silica source. The production of SBA-16 using Pluronic F127 as surfactant has led the material in forming spherical structure (Figure 1b). SBA-15 and SBA-16 were bind together with graphite powder via the help of paraffin oil (Figure 1c and Figure 1d).

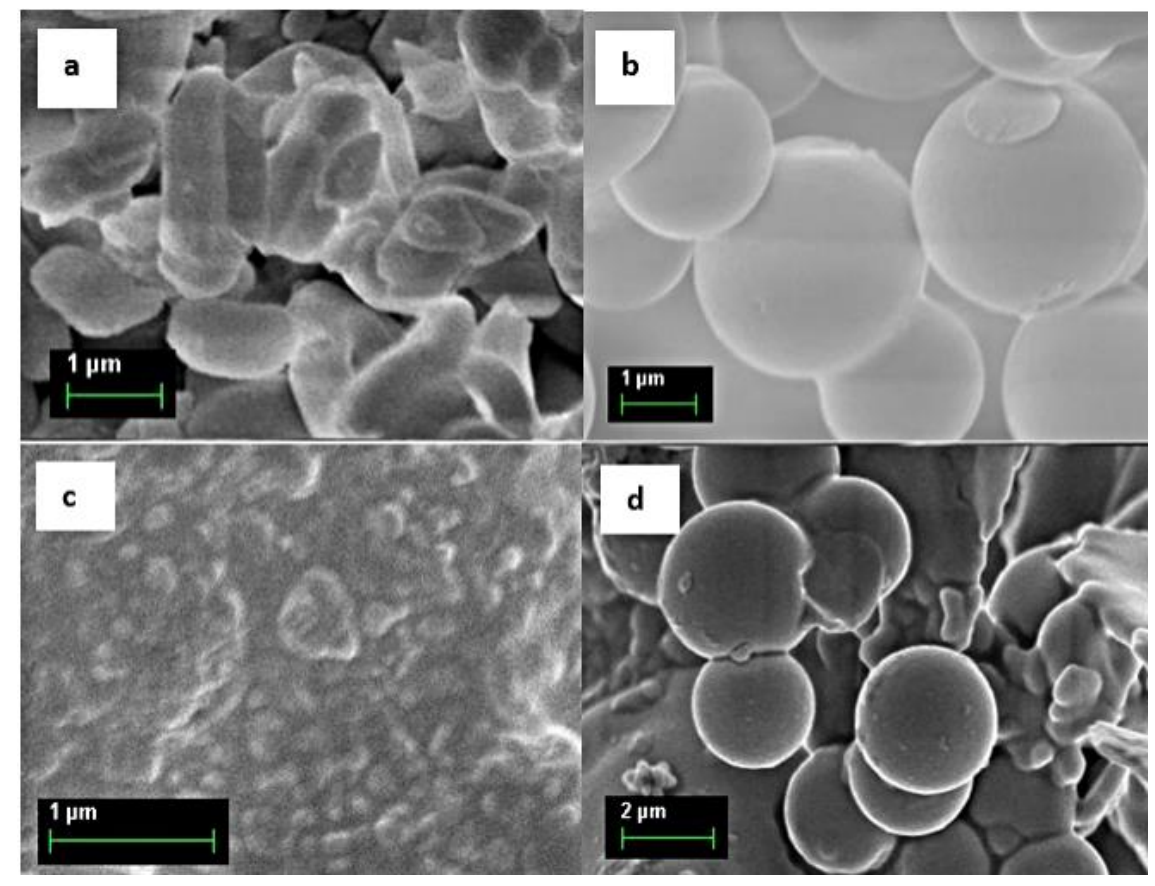

Figure 1. SEM images of SBA-15 and SBA-16. (a) SBA-15 (b) SBA-16 (c) SBA-15/MCPE (d) SBA-16/MCPE

Figure 2 shows X-Ray diffractograms obtained confirm that SBA-15 (diffractogram a) possess hexagonal mesostructure $[24,25]$ in which it shows three resolved peaks at lower angle $2 \theta=0.5-2.5^{\circ}$ which are indexed to (100), (110), and (200) that reflects as the well-ordered mesoporous silica, SBA-15 [26]. As evidence that SBA-16 materials possess a cubic ordering, three peaks of (110), (200), and (211) appears in diffractogram b [27]. The low intensities of peaks shown were discussed previously [28] that this may due to the thickness and roughness of pore walls [29]. 


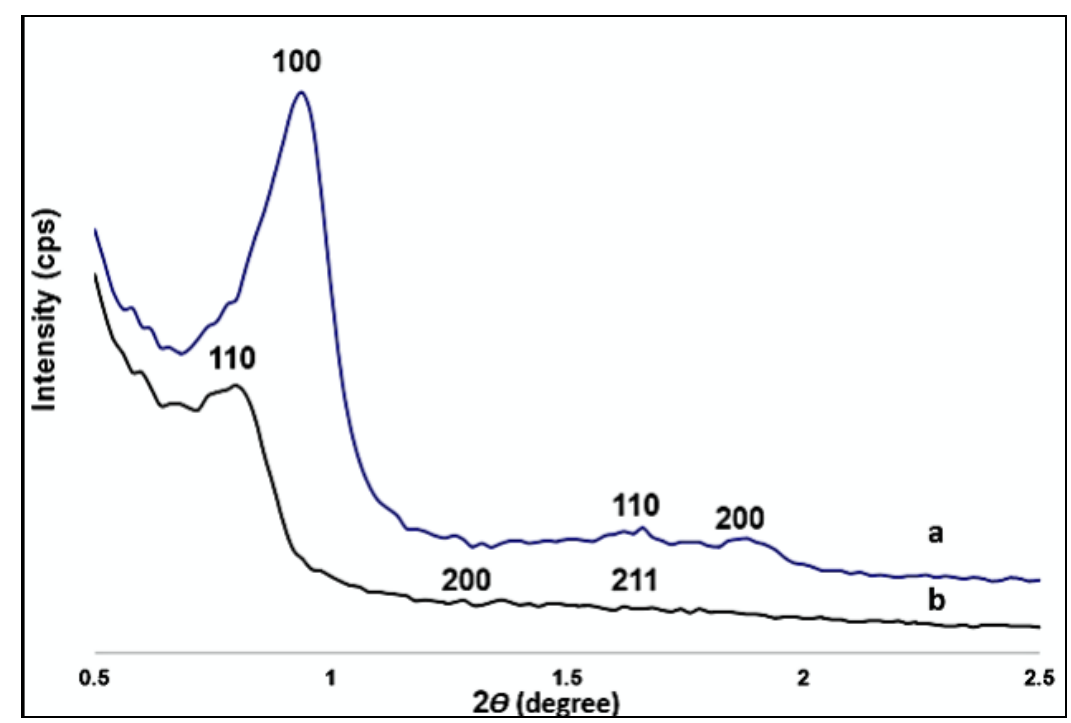

Figure 2. X-Ray diffraction. (A) SBA-15 (B) SBA-16

\section{The electrochemical behaviours}

The electrochemical behaviours of AA at three different sensors were studied by using cyclic voltammetry (CV). Figure 3 shows the $\mathrm{CV}$ results of $1.0 \times 10^{-3} \mathrm{M} \mathrm{AA}$ in $\mathrm{pH} 7$ phosphate buffer. During the anodic sweep from 0.00 to $1.00 \mathrm{~V}$, an oxidation peak at unmodified CPE (curve a) is observed at approximately $0.20 \mathrm{~V}$. Reduction peak does not appear which shows that the oxidation of AA is irreversible. When using SBA-15/MCPE (curve b) and SBA16/MCPE (curve c), the oxidation peaks are greatly enhanced. Curve b shows the oxidation peak of AA at $0.20 \mathrm{~V}$, and the oxidation peak for curve c slightly shifts positively from 0.20 to $0.27 \mathrm{~V}$.

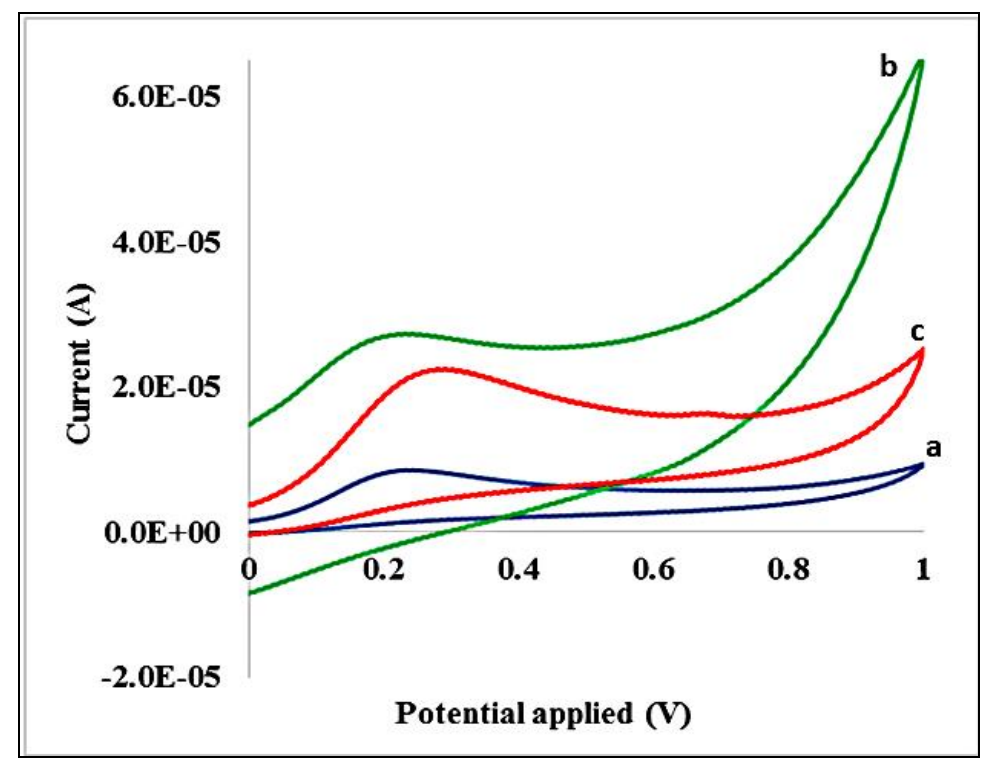

Figure 3. Cyclic voltammograms of $1.0 \times 1^{-3} \mathrm{M}$ AA in $\mathrm{pH} 7$ phosphate buffer at (a) unmodified CPE (b) SBA15/MCPE (c) SBA-16/MCPE . Number of cycle: 1 . Scan rate: $0.1 \mathrm{~V} \mathrm{~s}^{-}{ }^{1}$. 
Hence, this concludes that both modified sensors possess high efficiency of catalytic activity towards the oxidation of AA, which might be resulted from the short tunnelling distance between AA and porous electrodes. The peak currents of SBA-15/MCPE and SBA-16/MCPE are increased as well which reveals the surface enhancement effect that reflects to the unique properties of mesoporous silica (SBA-15 and SBA-16) consisting large surface are, high pore volume, and good pore network.

Figure 4 shows the CV curves of $1.0 \times 1^{-6} \mathrm{M}$ UA in $\mathrm{pH} 7$ phosphate buffer at unmodified CPE (curve a), SBA15/MCPE (curve b) and SBA-16/MCPE (curve c) sensors. During the anodic sweep from 0.20 to $1.00 \mathrm{~V}$, broad oxidation peaks appeared at $0.78 \mathrm{~V}$ for both unmodified CPE (curve a) and SBA-16/MCPE (curve c). SBA16/MCPE sensor slightly enhanced the oxidation peak current. Reduction peak does not appear which concludes that oxidation of UA is reversible. Curve $\mathrm{c}$ shows no oxidation and reduction peaks. By comparing both unmodified CPE and SBA-16/MCPE sensor, mesoporous silica (SBA-16) clearly provides the surface enhancement effect towards the detection of UA.

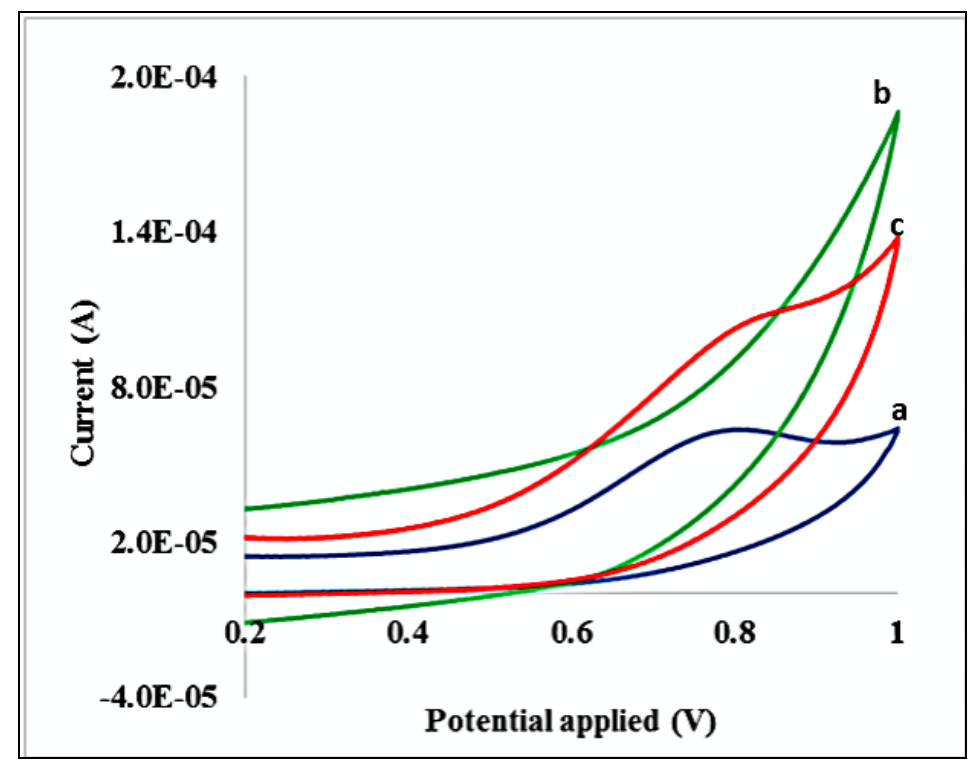

Figure 4. Cyclic voltammograms of $1.0 \times 1^{-6} \mathrm{M}$ UA in $\mathrm{pH} 7$ phosphate buffer at (a) unmodified CPE (b) SBA15/MCPE (c) SBA-16/MCPE. Number of cycle: 1 . Scan rate: $0.1 \mathrm{~V} \mathrm{~s}^{-}{ }^{1}$.

\section{Conclusion}

Two types of mesoporous silica, SBA-15 and SBA-16 was successfully synthesized using Pluronic P123 and F127 as directing agents with the presence of TEOS as the silica source. SBA-15 and SBA-16 were then used to build two different types of electrochemical sensors (SBA-15/MCPE and SBA-16/MCPE) for the detection of AA and UA. Due to the unique properties that the mesoporous silica possessed, the modified electrodes built exhibit greater surface enhancement towards the determination of AA and UA compared to the unmodified electrode by increasing the oxidation signals. Thus, it can reasonably be concluded that an enhanced, convenient and sensitive electrochemical method was developed to detect AA and UA.

\section{Acknowledgement}

The authors would like to thank the Research Management Institute (RMI), Universiti Teknologi MARA (UiTM) for financing the project under the Research Intensive Fund (600-RMI/DANA 5/3/RIF(395/2012) and highly appreciate the facilities provided by the Non-Destructive Biomedical and Pharmaceutical Research Centre of Faculty of Pharmacy from Universiti Teknologi Mara, Puncak Alam in analysing data. 


\section{References}

1. Cai, W., Lai, T., Du, H. and Ye, J. (2014). Electrochemical determination of ascorbic acid, dopamine and uric acid based on an exfoliated graphite paper electrode: A high performance flexible sensor. Sensors and Actuators B: Chemical, 193: 492 - 500.

2. Xu, X., Liu, Z., Zhang, X., Duan, S., Xu, S. and Zhou, C. (2011). ß-Cyclodextrin functionalized mesoporous silica for electrochemical selective sensor: Simultaneous determination of nitrophenol isomers. Electrochimica Acta, 58: 142 - 149.

3. Mazloum-ardakani, M., Sheikh-mohseni, M. A., Abdollahi-alibeik, M. and Benvidi, A. (2012). Chemical electrochemical sensor for simultaneous determination of norepinephrine, paracetamol and folic acid by a nanostructured mesoporous material. Sensors and Actuators B, 172: 380 - 386.

4. Yang, F., Xie, Q., Zhang, H., Yu, S., Zhang, X. and Shen, Y. (2015). Chemical Simultaneous determination of ascorbic acid, uric acid, tryptophan and adenine using carbon-supported $\mathrm{NiCoO}_{2}$ nanoparticles. Sensors and Actuators B, 210: 232 - 240.

5. Arrigoni, O. and De Tullio, M. C. (2002). Ascorbic acid: Much more than just an antioxidant. Biochimica et Biophysica Acta - General Subjects, 1569(1-3): 1 - 9.

6. Alderman, M. H. (2002). Uric acid and cardiovascular risk. Current Opinion in Pharmacology, 2(2): 126 - 130.

7. Wu, D., Li, Y., Zhang, Y., Wang, P., Wei, Q. and Du, B. (2014). Sensitive electrochemical sensor for simultaneous determination of dopamine, ascorbic acid, and uric acid enhanced by amino-group functionalized mesoporous $\mathrm{Fe}_{3} \mathrm{O}_{4} @$ Graphene Sheets. Electrochimica Acta, 116: 244 - 249.

8. Li, M., Guo, W., Li, H., Dai, W. and Yang, B. (2014). Electrochemical biosensor based on one-dimensional $\mathrm{MgO}$ nanostructures for the simultaneous determination of ascorbic acid, dopamine, and uric acid. Sensors and Actuators B: Chemical, 204: 629 - 636.

9. Mazloum-Ardakani, M., Sheikh-Mohseni, M. A., Beitollahi, H., Benvidi, A. and Naeimi, H. (2010). Electrochemical determination of vitamin $\mathrm{C}$ in the presence of uric acid by a novel $\mathrm{TiO}_{2}$ nanoparticles modified carbon paste electrode. Chinese Chemical Letters, 21 (12): 1471 - 1474.

10. Xu, T.-Q., Zhang, Q.-L., Zheng, J.-N., Lv, Z.-Y., Wei, J., Wang, A.-J. and Feng, J.-J. (2014). Simultaneous determination of dopamine and uric acid in the presence of ascorbic acid using Pt nanoparticles supported on reduced graphene oxide. Electrochimica Acta, 115: 109 - 115.

11. Yang, L., Liu, D., Huang, J. and You, T. (2014). Chemical Simultaneous determination of dopamine , ascorbic acid and uric acid at electrochemically reduced graphene oxide modified electrode. Sensors and Actuators B, 193: $166-172$.

12. Sun, D., Zhang, Y., Wang, F., Wu, K., Chen, J. and Zhou, Y. (2009). Electrochemical sensor for simultaneous detection of ascorbic acid, uric acid and xanthine based on the surface enhancement effect of mesoporous silica. Sensors and Actuators B: Chemical, 141 (2): 641 - 645.

13. Zeng, Y., Xu, J. and Wu, K. (2008). Electrochemical determination of uric acid using a mesoporous $\mathrm{SiO}_{2-}$ modified electrode. Microchimica Acta, 161(1-2): 249 - 253.

14. Beck, J. S., Vartuli, J. C., Roth, W. J., Leonowicz, M. E., Kresge, C. T., Schmitt, K. D., Chu, C. T. W., Olson, D. H. and Sheppard, E. W. (1992). A new family of mesoporous molecular sieves prepared with liquid crystal templates. Journal of the American Chemical Society, 114 (27): 10834 - 10843.

15. Hoffmann, F., Cornelius, M., Morell, J. and Fröba, M. (2006). Silica-based mesoporous organic-inorganic hybrid materials. Angewandte Chemie International Edition, 45 (20): 3216 - 3251.

16. Sun, D., Xie, X. and Zhang, H. (2010). Surface effects of mesoporous silica modified electrode and application in electrochemical detection of dopamine. Colloids and Surface B: Biointerfaces, 75 (1): 88 - 92.

17. Wang, F., Yang, J. and Wu, K. (2009). Mesoporous silica-based electrochemical sensor for sensitive determination of environmental hormone bisphenol A. Analytica Chimica Acta, 638 (1): 23 - 28.

18. Zhao, J., Huang, W. and Zheng, X. (2009). Mesoporous silica-based electrochemical sensor for simultaneous determination of honokiol and magnolol. Journal of Appied. Electrochemistry, 39 (12): 2415 - 2419.

19. Shimomura, T., Itoh, T., Sumiya, T., Mizukami, F. and Ono, M. (2008). Electrochemical biosensor for the detection of formaldehyde based on enzyme immobilization in mesoporous silica materials. Sensors and Actuators B: Chemcial, 135 (1): 268 - 275.

20. Sayari, A. H., Han, B.-H. and Yang, Y. (2004). Simple synthesis route to monodispersed SBA-15 silica rods. Journal of the American Chemical Sociecty., 126 (44): 14348 - 14349. 
21. Sun, R.-H. and Jun, W. (2007). The growth mechanism of continuous cubic mesoporous SBA-16 film with a large area of highly ordered pores. Nanotechnology, 18(18): 185705.

22. Boissiere, C., Grosso, D., Lepoutre, S., Nicole, L., Bruneau, A. B. and Sanchez, C. (2005). Porosity and mechanical properties of mesoporous thin films assessed by environmental ellopsometric porosimetry. Langmuir, 21 (26): 12362 - 12371.

23. Fathirad, F., Afzali, D., Mostafavi, A., Shamspur, T. and Fozooni, S. (2013). Fabrication of a new carbon paste electrode modified with multi-walled carbon nanotube for stripping voltammetric determination of bismuth(III). Electrochimica Acta, 103: 206 - 210.

24. Brodie-Linder, N., Dosseh, G., Alba-Simonesco, C., Audonnet, F. and Impéror-Clerc, M. (2008). SBA-15 synthesis: Are there lasting effects of temperature change within the first 10min of TEOS polymerization? Materials Chemistry and Physics, 108 (1): 73 - 81.

25. Dos Santos, S. M. L., Nogueira, M. De Souza Gama, J. D. F. Lima, Da Silva Júnior, I. J. and De Azevedo. D. C. S. (2013). Synthesis and characterization of ordered mesoporous silica (SBA-15 and SBA-16) for adsorption of biomolecules. Microporous and Mesoporous Materials, 180: 284 - 292.

26. Lin, C.-L., Pang, Y.-S., Chao, M.-C., Chen, B-C., Lin, H. P., Tang, C. Y. and Lin, C.-Y. (2008). Synthesis of SBA-16 and SBA-15 mesoporous silica crystals templated with neutral block copolymer surfactants. Journal of Physics and Chemistry of Solids, 69 (23): 415 - 419.

27. Shah, A. T., Ahmad, S., Khan, M. F., Shahzad, K., Tabassum, S. and Mujahid, A. (2014). In situ synthesis of copper nanoparticles on SBA-16 Silica Spheres. Arabian Journal of Chemistry (In Press): 2 - 6.

28. Wang, L., Fan, J., Tian, B., Yang, H., Yu, C., Tu, B. and Zhao, D. (2004). Synthesis and characterization of small pore thick-walled SBA-16 templated by oligomeric surfactant with ultra-long hydrophilic chains. Microporous and Mesoporous Materials, 67 (23): 135 - 141.

29. Stevens, W. J. J., Mertens, M., Mullens, S., Thijs, I., Van Tendeloo, G., Cool, P. and Vansant, E. F. (2006). Formation mechanism of SBA-16 spheres and control of their dimensions. Microporous and Mesoporous Materials, 93 (1-3): 119 - 124. 